\title{
AFLATOXINS, OCHRATOXIN A AND ZEARALENONE IN MAIZE-BASED FOOD PRODUCTS
}

\author{
Beatriz Leiko Sekiyama; Alessandra Braga Ribeiro; Paulo André Machinski; Miguel Machinski Junior*
}

Universidade Estadual de Maringá, Departamento de Análises Clínicas, Laboratório de Toxicologia, Maringá, PR, Brasil.

Submitted: August 02, 2004; Returned to authors for corrections: July 25, 2005; Approved: September 12, 2005

\begin{abstract}
The occurrence of aflatoxins $\mathrm{B}_{1}\left(\mathrm{AFB}_{1}\right), \mathrm{B}_{2}\left(\mathrm{AFB}_{2}\right), \mathrm{G}_{1}\left(\mathrm{AFG}_{1}\right)$ and $\mathrm{G}_{2}\left(\mathrm{AFG}_{2}\right)$, ochratoxin $\mathrm{A}(\mathrm{OA})$ and zearalenone (ZEA) was evaluated in 121 maize-based food samples collected in the commerce of Maringá City, Paraná State, Brazil. The study was carried out between January 2002 and February 2003. Thin-layer chromatographic method was used to determine the mycotoxins. The recovery averages were $106.6 \%, 109.4 \%, 106.6 \%, 109.4 \%$, $101.8 \%$ and $101.7 \%$ to $\mathrm{AFB}_{1}, \mathrm{AFB}_{2}, \mathrm{AFG}_{1}, \mathrm{AFG}_{2}, \mathrm{OA}$ and $\mathrm{ZEA}$, respectively. Three samples (2.5\%) were positive to $\mathrm{AFB}_{1}$ ( 8 to $59 \mu \mathrm{g} / \mathrm{kg}$ ), two $(1.7 \%)$ to $\mathrm{AFB}_{2}(2.4 \mu \mathrm{g} / \mathrm{kg})$, one $(0.8 \%)$ to $\mathrm{OA}(64 \mu \mathrm{g} / \mathrm{kg})$ and one $(0.8 \%)$ to ZEA $(448 \mu \mathrm{g} / \mathrm{kg})$. The greater frequency of positive samples and also the highest concentration of $\mathrm{AFB}_{1}$ were found in popcorn samples $(8.3 \%, 59 \mu \mathrm{g} / \mathrm{kg})$. The data showed a low frequency of mycotoxins in products based on maize traded in Maringá, but the Probable Average Daily Intake (PDI) of $\mathrm{AFB}_{1}$ in them was high. Therefore, it is necessary to accomplish an active vigilance of these mycotoxins in such food products in order to provide safety to Brazilian people health.
\end{abstract}

Key words: mycotoxins; risk; Brazilian products derived from maize

\section{INTRODUCTION}

Zummo and Scott (51) demonstrated that maize (Zea mays L.) is constantly exposed to the risk of fungi development for having ideal nutrients composition. Moreover, tropical and subtropical climate countries have favorable environmental conditions to the development of the main types of genotoxicant fungi, Aspergillus, Fusarium and Penicillium. Among the mycotoxins which are found in maize, aflatoxins, zearalenone and ochratoxin A are detached both for the concerning showed by the researchers due to their possible toxicant effect in human beings and animals and for economical reasons (6).

Aflatoxins are a group of mycotoxins produced by clumps of Aspergillus flavus (Link) and Aspergillus parasiticus (Speare). Four aflatoxins stand out: $\mathrm{B}_{1}\left(\mathrm{AFB}_{1}\right), \mathrm{G}_{1}\left(\mathrm{AFG}_{1}\right), \mathrm{B}_{2}$ $\left(A F B_{2}\right)$ and $G_{2}\left(A_{F G}\right)$. Aflatoxin $B_{1}$ is considered one of the most powerful human carcinogenic and also hepatoxic (11).

Ochratoxin $\mathrm{A}(\mathrm{OA})$ is mainly produced by fungi Aspergillus and Penicillium genus (50), where A. ochraceus (Wilhelm) and $P$. verucosum (Dierckx) are the main productive species of this mycotoxin. Ochratoxin A (OA) is mutagenic, teratogenic and nephrotoxic and has been involved in etiology of Balkan Endemic Nephropathy (7).

Zearalenone (ZEA) presents an estrogenic and anabolic action in several animals. Swine specie is the most affected (18), being caused endometrial hyperplasias, ovarium atrophy, nymphomania (8), pseudogestation, vulvovaginitis (42) and embryonic loss (27). In young male swines the toxin causes prepuce oedema, testicle atrophy and increasing of mammary gland (12). In relation to the toxic effects in human beings, there are cases in which ZEA was reported because it caused premature puberty in children aged between 7 and 8 years (35) and cases in Puerto Rico (41). This mycotoxin is mainly produced by Fusarium graminearum (Schwabe), Fusarium proliferatum (T Matsushima) Niremberg and Fusarium culmorum (Wm G Sm) Sacc.

Some reports have shown the occurrence of mycotoxins in maize in Brazil. Sabino et al. (40) found different levels of ZEA: from not detected (nd) to $9830 \mu \mathrm{g} / \mathrm{kg}$ in 358 maize samples; in respect to aflatoxins 44 samples were positive to $\mathrm{AFB}_{1,}$ from 5 to $900 \mu \mathrm{g} / \mathrm{kg}$. In another survey, Henningen and Dick (19) did not

*Corresponding Author. Mailing address: Universidade Estadual de Maringá, Departamento de Análises Clínicas, Laboratório de Toxicologia. Av. Colombo, 5790. 87020-900, Maringá, PR, Brasil. Fonefax: (+5544) 3261-4489. E-mail: mmjunior@uem.br 
detect ZEA in the 23 maize samples stocked in silos. However, they found aflatoxins in $34.8 \%$ of the samples and the sum of $\mathrm{AFB}_{1}+\mathrm{AFG}_{1}$ varied from 12 to $906 \mu \mathrm{g} / \mathrm{kg}$. Machinski Jr. et al. (29) demonstrated a high aflatoxin contamination in the new crop maize. The authors found $54.5 \%$ of positive samples in a total concentration $\left(\mathrm{AFB}_{1}+\mathrm{AFB}_{2}+\mathrm{AFG}_{1}+\mathrm{AFG}_{2}\right)$ varying from 0.6 to $1792 \mu \mathrm{g} / \mathrm{kg}$.

The present paper studied the occurrence of aflatoxins, ochratoxin A and zearalenone in food products based on maize, commercialized in the city of Maringá, Paraná, Brazil, in the period from January 2002 to February 2003. The exposure of Brazilian people to the mycotoxins was also evaluated according to the consumption of maize and its derivatives.

\section{MATERIALS AND METHODS}

\section{Samples}

Between January 2002 and February 2003, a hundred and twenty one samples of maize-based food products were collected by the Municipal Sanitary Vigilance in markets in Maringá City, Paraná, Brazil. The collected samples were: 37 packs of degerminated corn, 17 packs of corn flour, 10 packs of corn flakes, 26 packs of corn meal, 24 packs of popcorn and 7 packs of corn grits. The minimum size of the pack of each sample was $500 \mathrm{~g}$. The samples were ground, homogenized and stocked in a temperature of $-20^{\circ} \mathrm{C}$ until the analysis.

\section{Analytical standards}

The standards of mycotoxins were obtained from Sigma Chemical Co. (USA) and the preparation of the standard solutions was accomplished according to the Manual of Official Methods of Analysis of Association of Official Analytical Chemists (3). From the individual stock solutions to each toxin and after determining the exact concentration by ultraviolet spectrometry, a work solution with a mixture of toxins was prepared: $5 \mu \mathrm{g} / \mathrm{mL}$ to $\mathrm{AFB}_{1}$ and $\mathrm{G}_{1}, 1.5 \mu \mathrm{g} / \mathrm{mL}$ to $\mathrm{AFB}_{2}$ and $\mathrm{G}_{2}, 10 \mu \mathrm{g} / \mathrm{mL}$ to $\mathrm{OA}$ and $40 \mu \mathrm{g} / \mathrm{mL}$ to ZEA in benzeneacetonitrile $(98: 2, \mathrm{v} / \mathrm{v})$.

\section{Extraction, cleanup, quantification and confirmation by thin- layer chromatography}

The determination of aflatoxins, ochratoxin A and zearalenone was accomplished according to the method described by Soares and Rodriguez-Amaya (45) by thin-layer chromatography. Fifty grams of sample were homogenized in a blender with $270 \mathrm{~mL}$ of methanol and $30 \mathrm{~mL}$ of $4 \%$ potassium chloride during 5 minutes. The mixture was filtered in common paper filter. A hundred and fifty $\mathrm{mL}$ of the filtered mixture were transferred to a glass where $150 \mathrm{~mL}$ of $30 \%$ ammonium sulfate and $50 \mathrm{~mL}$ of Celite during 5 minutes. The mixture was filtered in common paper filter. A hundred and fifty $\mathrm{mL}$ of the filtered mixture were transferred to a separation funnel and were added $150 \mathrm{~mL}$ of water and partitioned twice with $10 \mathrm{~mL}$ of chloroform. Five $\mathrm{mL}$ from the first and from the second partition of the chloroform were combined. It evaporated because of the dryness in a bath with water at a temperature of $80^{\circ} \mathrm{C}$. Five $1 / 4 \mathrm{~L}$ from the extract were applied in the chromatoplate (silicagel 60G, MN). The standards were applied separately. The plate was placed in a unsaturated tank containing toluene-ethyl acetate-chloroform-formic acid (70:50:50:20, v/v/ $\mathrm{v} / \mathrm{v}$ ). The aflatoxins and ochratoxin A were visualized by incidence of the long UV light. Then the chromatoplate was reveled with a aluminum chloride solution to evaluate the presence of zearalenone. Known volumes of sample and standards were applied in the chromatoplates to the quantification. To the quantification of aflatoxins the plates were developed in the previous described solvent system; to ochratoxin A, tolueneethyl acetate-chloroform-formic acid was used (5:4:1, v/v/v) and to zearalenone, toluene-ethyl acetate-chloroform-formic acid was used $(60: 40: 0,5, \mathrm{v} / \mathrm{v} / \mathrm{v})$ and posterior revealing with aluminum chloride. All calculations were done according to the Manual of Official Methods of Analysis of AOAC (3).

The toxins identity was confirmed by reactions of derivation and evaluated with the standards by thin-layer chromatography. Aflatoxins were derived with trifluoroacetic acid according to Przybylski (38). Zearalenone was acetylated with acetic anhydride in the presence of pyridine as described by Golinski and Grabarkiewicz-Szczena (16). Ochratoxin A was methylated with boron trifluoride in methanol according to the procedure of Hunt et al. (21).

\section{Analytical quality control}

All samples were analyzed in duplicate with each duplicate on a different day. Each group of nine determinations was accompanied by a spiked, that is, to the samples extracted in the same day an amount of mycotoxins was added to a known sample in the day before the extraction. These samples were used to evaluate the recovery and the quantification, so that all results could be corrected by the found recovery. The following analytical quality criteria were defined: recovery should be between 65 and $135 \%$ and the coefficient of variation between the duplicates should be less than $30 \%$ according of Horwitz et al . (20).

\section{Chemicals}

Sovents and salts are from Merck S.A. (Rio de Janeiro, Brazil).

\section{RESULTS AND DISCUSSION}

The average recovery of the method was $106.6 \%$ to aflatoxin $\mathrm{B}_{1}, 109.4 \%$ to $\mathrm{B}_{2}, 106.6 \%$ to $\mathrm{G}_{1}, 109.4 \%$ to $\mathrm{G}_{2}, 101.8 \%$ to ochratoxin A and $101.7 \%$ to zearalenone, according to Table 1 . The detection limits were 2, 0.96, 2, 0.48, 6.4 and $76.81 / 4 \mathrm{~g} / \mathrm{kg}$ respectively to $\mathrm{AFB}_{1}, \mathrm{AFB}_{2}, \mathrm{AFG}_{1}, \mathrm{AFG}_{2}, \mathrm{OA}$ and $\mathrm{ZEA}$.

The aflatoxins were detected in 2.5\% (3/121) of all analyzed products, in a total concentration $\left(\mathrm{AFB}_{1}+\mathrm{AFB}_{2}\right)$ which varied 
Table 1. Recovery of mycotoxins from some maize matrices.

\begin{tabular}{lcccccc}
\hline & \multicolumn{6}{c}{ Recovery (\%) } \\
\cline { 2 - 7 } \multicolumn{1}{c}{ Products } & $\mathrm{AFB}_{1}$ & $\mathrm{AFB}_{2}$ & $\mathrm{AFG}_{1}$ & $\mathrm{AFG}_{2}$ & $\mathrm{OA}$ & ZEA \\
\hline $\begin{array}{l}\text { 1. Yellow } \\
\text { degerminated } \\
\text { corn }\end{array}$ & 100 & 133 & 100 & 133 & 100 & 100 \\
2. White & 133 & 133 & 133 & 133 & 133 \\
$\quad$ degerminated & 88 & 100 & 100 & 100 & 100 & 100 \\
$\quad$ corn & 100 & 100 & 100 & 100 & 100 & 100 \\
3. Corn flour & 100 & 100 & 100 & 100 & 100 & 100 \\
4. Corn flakes & 100 & 100 & 100 & 100 & 100 & 100 \\
5. Corn meal & 100 & 100 & 100 & 100 & 100 & 100 \\
& 100 & 100 & 100 & 100 & 100 & 100 \\
6. Popcorn & 100 & 100 & 100 & 100 & 100 & 100 \\
& 100 & 100 & 100 & 100 & 100 & 100 \\
7. Corn grits & 131 & 133 & 131 & 133 & 100 & 100 \\
\hline Average (\%) & 133 & 133 & 133 & 133 & 100 & 100 \\
\hline
\end{tabular}

from 10.4 to $59 \mu \mathrm{g} / \mathrm{kg}$. Among the positive samples three of them presented $\mathrm{AFB}_{1}$ in concentration varying from 8 to $59 \mu \mathrm{g} /$ $\mathrm{kg}$ and two of them had $\mathrm{AFB}_{2}$ in concentration of $2.4 \mu \mathrm{g} / \mathrm{kg}$. The result of the positive samples is summarized in Table 2. Among the analyzed samples only two popcorn samples and one of corn grits presented positive results to aflatoxins.

The results found to aflatoxins were similar to other results found by various authors. Furlong et al. (14) reported that 7.7\% of 39 analyzed samples presented contamination with aflatoxins. Pich et al. (37) found levels from 3 to $24 \mu \mathrm{g} / \mathrm{kg}$ in 29 samples of corn flour analyzed. Soares and Rodriguez-Amaya (45) verified that 5 samples among 130 analyzed ones contained 20 to $47 \mu \mathrm{g} /$ $\mathrm{kg}$ of $\mathrm{AFB}_{1}$ in several products derived from maize.
The products derived from maize showed low contamination by aflatoxins; just $2.5 \%$ of the samples were positive and these results were partially similar to investigations in other parts of the world, like the results reported by Solovey et al. (46) that among 37 samples of food products derived from maize, originating from Argentina, there was not any detection of aflatoxins and also like the results from Abdulkadar et al. (1) that observed a contamination of 1 to $2 \mu \mathrm{g} / \mathrm{kg}$ in three of the 54 samples of maize and derivatives, originating from Qatar.

The contamination level of products derived from maize with aflatoxins is considerably lower than the found level to the non-processed maize; several studies prove this assertion like Ali et al. (2) who reported a total of $69 \%$ of samples from Indonesia which were contaminated in average levels of 119 $\mu \mathrm{g} / \mathrm{kg}$; Bhat et al. (4) considered $25.8 \%$ of contaminated samples with amounts over than $30 \mu \mathrm{g} / \mathrm{kg}$ in India; Glória et al. (15) verified $33 \%$ of contamination in samples originating from five Brazilian states; Vargas et al. (48) reported 38.3\% of contamination in samples from Brazilian different regions with average levels of $9.4 \mu \mathrm{g} / \mathrm{kg}$; Henningen and Dick (19) mentioned $30.5 \%$ of samples originating from South of Brazil, with variable levels from 10 to $906 \mu \mathrm{g} / \mathrm{kg}$; Li et al. (26) reported $35 \%$ of contaminated samples with average levels of $82 \mu \mathrm{g} / \mathrm{kg}$ in China; Machinski Jr. et al. (29) found 54.5\% of cultivated samples in experimental fields in Brazil, with levels varying from 6 to $1600 \mu \mathrm{g} / \mathrm{kg}$; Medina-Martinez and Martinez (31) verified contamination in $16.6 \%$ of analyzed samples originating from Venezuela; Ono et al. (34) reported $11.3 \%$ of contaminated samples from Brazil with average levels of $190 \mu \mathrm{g} / \mathrm{kg}$; Nepote et al. (33) mentioned $10 \%$ of contamination in samples originating from Argentina with concentrations over $20 \mu \mathrm{g} / \mathrm{kg}$ also in Argentina, González et al. (17) did not report any contamination by aflatoxins in 30 analyzed samples.

One sample of corn four $(0.8 \%)$ demonstrated an amount of $64 \mu \mathrm{g} / \mathrm{kg}$ of ochratoxin A (OA) that exceeded the maximum permitted limit of legislation from most of countries. Therefore, products derived from maize presented a low contamination by ochratoxin A. This result differ from the results obtained by Paolo and Tosi (36) who mentioned contents of 1250 to $2500 \mu \mathrm{g} / \mathrm{kg}$ in

Table 2. Content of aflatoxins, ochratoxin A and zearalenone found in food products based on maize purchased in markets of Maringá City, January/2002 to February/2003.

\begin{tabular}{|c|c|c|c|c|c|c|c|c|c|c|c|c|}
\hline \multirow{2}{*}{ Products } & \multicolumn{4}{|c|}{$\begin{array}{c}\text { Incidence } \\
\left(\mathrm{n}^{\mathrm{o}} \text { of positive/total samples) }\right.\end{array}$} & \multicolumn{2}{|l|}{$\mathrm{AFB}_{1}$} & \multicolumn{2}{|l|}{$\mathrm{AFB}_{2}$} & \multicolumn{2}{|l|}{$\mathrm{OA}$} & \multicolumn{2}{|l|}{ ZEA } \\
\hline & $\mathrm{AFB}_{1}$ & $\mathrm{AFB}_{2}$ & $\mathrm{OA}$ & ZEA & $\begin{array}{c}\text { Average of } \\
\text { positive samples }\end{array}$ & $\begin{array}{l}\text { Range } \\
(\mu \mathrm{g} / \mathrm{kg})\end{array}$ & $\begin{array}{c}\text { Average of } \\
\text { positive samples }\end{array}$ & $\begin{array}{l}\text { Range } \\
(\mu \mathrm{g} / \mathrm{kg})\end{array}$ & $\begin{array}{c}\text { Average of } \\
\text { positive samples }\end{array}$ & $\begin{array}{l}\text { Range } \\
(\mu \mathrm{g} / \mathrm{kg})\end{array}$ & $\begin{array}{c}\text { Average of } \\
\text { positive samples }\end{array}$ & $\begin{array}{l}\text { Range } \\
(\mu \mathrm{g} / \mathrm{kg})\end{array}$ \\
\hline Corn flour & nd & nd & $1 / 17$ & nd & - & - & - & - & 64 & 64 & - & - \\
\hline Popcorn & $2 / 24$ & $1 / 24$ & nd & $1 / 24$ & 33.5 & $8-59$ & 2.4 & 2.4 & - & - & 448 & 448 \\
\hline Corn grits & $1 / 7$ & $1 / 7$ & nd & nd & 21.3 & 21.3 & 2.4 & 2.4 & - & - & - & - \\
\hline
\end{tabular}

$\mathrm{nd}=$ not detected (detection limit: $\mathrm{AFB}_{1} 2 \mathrm{ppb}, \mathrm{AFB}_{2} 0.96 \mathrm{ppb} \mathrm{AFG}_{1} 2 \mathrm{ppb}, \mathrm{AFG}_{2} 0.48 \mathrm{ppb}$, ochratoxin 6.4 ppb and zearalenone $76.8 \mathrm{ppb}$ ) 
all samples of food products derived from maize originating from Argentina. This work corroborates the low contamination by ochratoxin A in food products derived from maize in Brazil. Such results may be compared to other studies accomplished by Caldas et al. (5), Furlong et al. (14), Hennigen and Dick (19), Soares (43), Soares and Furlani (44) and Soares and Rodriguez-Amaya (45).

Non-processed maize presents a level of contamination by ochratoxin A higher than the level found in products derived from maize. Veldman et al. (49) demonstrated a total of $16.7 \%$ of maize samples originating from Holland contaminated by OA with average level of $73 \mu \mathrm{g} / \mathrm{kg}$. Ministry of Agriculture, Fishing and Food of United Kingdom (30) reported that $10.1 \%$ of crude maize samples originating from countries like France, Argentina, Spain, Hungary and Germany were contaminated with amounts less than $1.5 \mu \mathrm{g} / \mathrm{kg}$ of OA. In Brazil, Machinski Jr. et al. (29) mentioned two samples (1.8\%) of maize contaminated with ochratoxin A (128 and $206 \mu \mathrm{g} / \mathrm{kg}$ ).

From the obtained results zearalenone was registered in only one sample of popcorn, in concentration of $448 \mu \mathrm{g} / \mathrm{kg}$. Knowing that the maximum limit of zearalenone in samples from most of countries is $200 \mu \mathrm{g} / \mathrm{kg}$ (30), we observe that, in spite of the low frequency of this mycotoxin in analyzed foods, the detected level in the positive sample must be considered as an important factor for it may cause toxic effect to human beings.

This result was similar to the studies carried out by Soares and Rodriguez-Amaya (45) who did not detect zearalenone in 296 samples of food collected in markets of Campinas, Brazil and Furlong et al. (14) reported $2.6 \%$ of samples originating from South of Brazil, with level of $163 \mu \mathrm{g} / \mathrm{kg}$.

Zearalenone has been found in maize in many parts of the world $(10,29,40,47)$. It is notorious that countries with hot climate have not been presented problems concerned to contamination by ZEA with maize. However, countries with cold and temperate climates have presented high levels and high percentages of contamination by this toxin in maize $(13,19,25,28,32,39)$.

Even knowing that the occurrence of mycotoxins is low in foods derived from maize commercialized in Brazil, there is a necessity of a constant vigilance of these foods aiming to provide quality and safety to all consumers because there are many different factors which influence the development of fungi and production of toxins, such as temperature, humidity, levels of intergranule oxygen, mechanical damages to the grain, among others, and these results may vary in products originating from different crops.

Daily consumption of maize and its derivatives in Brazil is 42 grams per person (22). Kuiper-Goodman (24) established a Tolerable Daily Intake (TDI) to aflatoxin $\mathrm{B}_{1}$ of $0.15 \mathrm{ng} / \mathrm{kg}$ bw/ day. Considering that the average weight of adult population is $70 \mathrm{~kg}$ and the average concentration of aflatoxin $\mathrm{B}_{1}$, in this study, is $0.7298 \mu \mathrm{g} / \mathrm{kg}$, Probable Average Daily Intake (PDI) is $0.4379 \mathrm{ng} / \mathrm{kg}$ bw/day. Therefore, the estimated average consumption of aflatoxin $\mathrm{B}_{1}$ was high in the analyzed food products derived from maize. This may contribute to an increase of incidence of hepatocellular carcinoma, so there is a significant risk to the health of Brazilian people due to the chronic exposure to aflatoxin $B_{1}$ in diets with foods derived from maize.

In respect to ochratoxin A, Temporary Tolerable Week Intake (TWI) is $0.1 \mu \mathrm{g} / \mathrm{kg}$ bw/week (23). Nevertheless, if we consider that the average concentration of ochratoxin A in the analyzed samples was $0.5289 \mu \mathrm{g} / \mathrm{kg}$, the Average Probable Week Intake (PWI) will be $0.0022 \mu \mathrm{g} / \mathrm{kg}$ bw/week. Temporary Tolerable Maximum Daily Intake (TMDI) of ZEA is $0.5 \mu \mathrm{g} / \mathrm{kg}$ bw (9). Knowing that the average concentration of ZEA in the analyzed samples was $3.7025 \mu \mathrm{g} / \mathrm{kg}$, we have the information that the Average Probable Daily Consumption will be $0.0022 \mu \mathrm{g} / \mathrm{kg}$ bw/ day. We conclude that the food products derived from maize do not contribute much to the consumption of ochratoxin A and zearalenone by Brazilian people.

\section{ACKNOWLEDGEMENTS}

A research grant from the Conselho Nacional de Desenvolvimento Científico e Tecnológico (CNPq-Brasil), grant $n^{\circ} 420207 / 01-5$, and a scholarship for the first author are gratefully acknowledged.

\section{RESUMO}

\section{Aflatoxinas, ocratoxina A e zearalenona em produtos alimentícios à base de milho}

A ocorrência de aflatoxinas $\mathrm{B}_{1}\left(\mathrm{AFB}_{1}\right), \mathrm{B}_{2}\left(\mathrm{AFB}_{2}\right), \mathrm{G}_{1}\left(\mathrm{AFG}_{1}\right)$ $\mathrm{e}_{2}\left(\mathrm{AFG}_{2}\right)$, ocratoxina $\mathrm{A}(\mathrm{OA})$ e zearalenona (ZEA) foi avaliada em 121 amostras de alimentos à base de milho, que foram coletadas no comércio da cidade de Maringá, PR, Brasil, entre os meses de Janeiro/2002 a Fevereiro/2003. A cromatografia em camada delgada foi empregada para a determinação das micotoxinas. As médias das recuperações foram 106,6\%, 109,4\%, $106,6 \%, 109,4 \%, 101,8 \%$ e $101,7 \%$ para $\mathrm{AFB}_{1}, \mathrm{AFB}_{2}, \mathrm{AFG}_{1}, \mathrm{AFG}_{2}$, OA e ZEA, respectivamente. Três amostras $(2,5 \%)$ foram positivas para $\mathrm{AFB}_{1}(8$ a $59 \mu \mathrm{g} / \mathrm{kg})$, duas $(1,7 \%)$ para $\mathrm{AFB}_{2}(2,4$ $\mu \mathrm{g} / \mathrm{kg})$, uma $(0,8 \%)$ para OA $(64 \mu \mathrm{g} / \mathrm{kg})$ e uma $(0,8 \%)$ para ZEA $(448 \mu \mathrm{g} / \mathrm{kg})$. A maior freqüência de amostras positivas e também a mais alta concentração de $\mathrm{AFB}_{1}$ foi encontrada nas amostras de pipoca $(8,3 \%, 59 \mu \mathrm{g} / \mathrm{kg})$. Os dados demonstraram uma baixa freqüência de micotoxinas em produtos à base de milho comercializados em Maringá, mas a Ingestão Diária Provável Média $\left(\mathrm{IDP}_{\mathrm{M}}\right)$ de $\mathrm{AFB}_{1}$ foi alta nos produtos analisados. Portanto, torna-se necessário a realização de uma vigilância ativa destas micotoxinas nestes produtos alimentícios, a fim de proporcionar segurança à saúde da população brasileira.

Palavras-chave: micotoxinas, risco, produtos brasileiros derivados do milho 


\section{REFERENCES}

1. Abdulkadar, A.H.W.; Abdulla, A.A.; Al-Jedah, J.H. Occurrence of aflatoxin in commodities imported into Qatar, 1997-2000. Food Addit. Contam., 19(7), 666-670, 2002.

2. Ali, N.; Sardjono, Yamashita, A.; Yoshizawa, T. Natural co-occurrence of aflatoxins and Fusarium Mycotoxins (fumonisins, deoxynivalenol, nivalenol and zearalenone) in corn from Indonesia. Food Addit. Contam., 15(4), 377-384, 1998.

3. AOAC. Official Methods of Analysis of the Association of Official Analytical Chemists, $16^{\text {th }}$ ed. Method 971.22; 985.17. The Association: Arlington, Washington, 1995.

4. Bhat, R.V.; Vasanthi, S.; Rao, S.B.; Rao, N.R.; Rao, S.V.; Nagaraja, K.V.; Bai, N.R.; Prasad, K.; Vanchinathan, S.; Roy, R.; Saha, S.; Mukherjee, A.; Ghosh, P.K.; Toteja, G.S.; Saxena, B.N. Aflatoxin B contamination in maize samples collected from different geographical regions of India - a multicentre study. Food Addit. Contam., 14(2), 151-156, 1997.

5. Caldas, E.D.; Silva, S.C.; Oliveira, J.N. Aflatoxinas e ocratoxina A em alimentos e riscos para a saúde humana. Rev. Saúde Pública, 36(3), 319-323, 2002.

6. CAST. Mycotoxins: Economic and Health Risks. Council for Agricultural Science and Technology Task Force Report, $n^{\circ} 116$, 1 A, 1989.

7. Castegnaro, M.; Barstch, H.; Chernozemsky, I. Endemic nephropathy and urinary tract tumors in the Balkans. Cancer Res., 47, 36083609, 1987.

8. Chang, K.; Kurtz, H.J.; Mirocha, C.J. Effects of the mycotoxin zearalenone on swine reproduction. Am. J. Vet. Res., 40, 12601267, 1979.

9. Creppy, E.E. Update of survey, regulation and toxic effects of mycotoxins in Europe. Toxicol. Lett., 127, 19-28, 2002.

10. Doko, M.B.; Canet, C.; Brown, N.; Sydenham, E.W.; Mpuchane, S.; Siame, B.A. Natural co-occurrence of fumonisins and zearalenone in cereals and cereal-based foods from Eastern and Southern Africa. $J$. Agric. Food Chem., 44(10), 3240-3243, 1996.

11. Eaton, D.L.; Groopman, J.D. (Eds.. The Toxicology of Aflatoxins: Human Health, Veterinary and Agricultural Significance, Academic Press, San Diego, 1994.

12. Edwards, S.; Cantley, T.C.; Day, B.N. The effects of zearalenone on reproduction in swine II. Theriogenol., 28, 51-58, 1987.

13. Eppley, R.M.; Stoloff, L.; Trucksess, M.W.; Chung, C.W. Survey of corn for Fusarium toxins. J. Assoc. Off. Anal. Chem., 57, 632-635, 1974.

14. Furlong, E.B.; Soares, L.A.S.; Vieira, A.P.; Dadalt, G. Aflatoxinas, Ocratoxina A e Zearalenona em alimentos da região Sul do Rio Grande do Sul. Rev. Inst. Adolfo Lutz, 58, 105-111, 1999.

15. Glória, E.M.; Fonseca, H.; Souza, I.M. Occurrence of mycotoxins in maize delivered to the food industry in Brasil. Trop. Sci., 37, 107110, 1997.

16. Golinski, P.; Grabarkiewicz-Szczesna, J. Chemical confirmatory tests for ochratoxin A, citrinin, penicillic acid, sterigmatocystin, and zearalenone performed directly on thin layer chromatographic plates. J. Assoc. Off. Anal. Chem., 67(6), 1108-1110, 1984.

17. González, H.H.L.; Martínez, E.J.; Pacin, A.M.; Resnik, S.L.; Sydenham, E.W. Natural co-occurrence of fumonisins, deoxyvalenol, zearalenone and aflatoxins in field trial corn in Argentina. Food Addit. Contam., 16(12), 565-569, 1999.

18. Haggler, W.M. JR.; Towers, N.R.; Mirocha, C.J.; Eppley, R.M.; Bryden, W.L. Zearalenone: Mycotoxin or mycoestrogen? Fusarium: Paul E. Nelson Memorial Symposium, edited by B.A. Summerell, J.F. Leslie, D. Bachouse, W.L. Bryden; L.W. Burges (St. Paul: APS Press), p. 321-331, 2001.

19. Henningen, M.R.; Dick, T. Incidence and abundance of mycotoxins in maize in Rio Grande do Sul, Brazil. Food Addit. Contam., 12(5), 677-681, 1995.
20. Horwitz, W.; Albert, R.; Nesheim, S. Reliability of mycotoxin assays - an update. J. AOAC Int., 76, 461-491, 1993.

21. Hunt, D.C.; McConnie, B.R.; Crosby, N.T. Confirmation of ochratoxin A by chemical derivatisation and high-performance liquid chromatography. Analyst, 105, 89-91, 1980.

22. IBGE. Estudo Nacional de Despesa Familiar, Fundação Instituto Brasileiro de Geografia e Estatística, Rio de Janeiro, volumes 1-5, 1977.

23. JECFA. Safety evaluation of certain food additives and contaminants - Ochratoxin A. World Heath Organization, 1995.

24. Kuiper-Goodman, T. Mycotoxins: risk assessment and legislation. Toxicol. Lett., 82/83, 853-859, 1995.

25. Lauren, D.R.; Agnew, M.P.; Smith, W.A.; Sayer, S.T. A survey of the natural occurrence of Fusarium mycotoxins in cereals grown in New Zealand in 1986-1989. Food Addit. Contam., 8(5), 599-605, 1991.

26. Li, F.Q.; Yoshizawa, T.; Kawamura, O.; Luo, X.Y.; Li, Y.W. Aflatoxins and fumonisins in corn from the high-incidence area for human hepatocellular carcinoma in Guangxi, China. J. Agric. Food Chem., 49, 4122-4126, 2001.

27. Long, G.G.; Dieckman, M.A. Characterization of effects of zearalenone in swine during early pregnancy. Am. J. Vet. Res., 47, 184-187, 1986.

28. L'Vova, L.S.; Orlova, N.Y.; Bystryakova, Z.K.; Omel'Chenko, M.D., Remele, V.V. Occurrence of toxigenic fungi and mycotoxins in various crop grains. Prikl. Biokhim. Mikrobiol., 29, 70-79, 1993.

29. Machinski Jr., M.; Soares, L.M.V.; Sawazaki, E.; Bolonhezi, D.; Castro, J.L.; Bortolleto, N. Aflatoxins, ochratoxin A and zearalenone in Brazilian corn cultivars. J. Sci. Food Agric., 81, 1001-1007, 2001.

30. MAFF. Survey for aflatoxins, ochratoxin A, fumonisins and zearalenone in raw maize. Food Contaminants Division, 2002. Disponível; em: <http:://www.fssg.maff.gov.uk/.

31. Medina-Martínez, M.S.; Martínez, A.J. Mold occurrence and aflatoxin $\mathrm{B}_{1}$ determination in corn samples in Venezuela. J. Agric. Food Chem., 48, 2833-2836, 2000.

32. Milanez, T.V.; Atui, M.B.; Lázzari, F.A. Comparação entre imunoensaio e cromatografia em camada delgada na determinação de aflatoxinas, ocratoxina A e zearalenona em amostras de milho em grão e fubá. Rev. Inst. Adolfo Lutz, 57(1), 65-71, 1998.

33. Nepote, M.C.; Piontelli, L.E.; Saubois, A. Occurrence of Aspergillus flavus strains and aflatoxins in corn from Santa Fe, Argentina. Archiv. Lat. Nutr., 47(3), 262-264, 1997.

34. Ono, E.Y.S.; Ono, M.A.; Funo, F.Y.; Medina, A.E.; Oliveira, T.C.R.M.; Kawamura, O.; Ueno, Y.; Hirooka, E.Y. Evaluation of fumonisin-aflatoxin co-occurrence in Brazilian corn-hybrids by Elisa. Food Addit. Contam., 18(8), 719-729, 2001.

35. Painter, K. Puberty signs evident in 7-and 8-year old girls. USA Today, April 8, P.A-1, 1997.

36. Paolo, O.D.; Tosi, E.A. Contaminacion de harina de maiz con ochratoxina A, aflatoxina y zearalenona. Alimentaria, 67, 1998.

37. Pich, P.H.; Nordin, N.S.D.; Noll, I.B. Detecção de aflatoxinas em produtos derivados de milho comercializados na região de Porto Alegre-RS. IX Encontro Nacional de Micotoxinas, Florianópolis, 1998, p. 120.

38. Przybykski, W. Formation of aflatoxin derivatives on thin layer chromatographic plates. J. Assoc. Off. Anal. Chem., 58(1), $163-$ $164,1975$.

39. Rheeder, J.P.; Sydenham, W.E.; Marasas, W.F.O.; Thiel, P.G.; Shephard, G.S.; Schlechter, M.; Stockenström, S.; Cronje, D.W.; Viljoen, J.H. Fungal infestation and mycotoxin contamination of South African commercial maize harvested in 1989 and 1990. South Afr. J. Sci., 91, 127-131, 1995.

40. Sabino, M.; Prado, G.; Inomata, E.I.; Pedroso, M.O.; Garcia, R.V. Natural occurrence of aflatoxins and zearalenone in maize in Brasil. Part II. Food Addit. Contam., 6(3), 327-331, 1989. 


\section{B.L. Sekiyama et al.}

41. Saenz De Rodriguez, C.A.; Bangiovanni, A.M.; Conde De Borrego, D. An epidemic of precocious development in Puerto Rican children. J. Pediatr., 393-396, 1985.

42. Shier, W.T.; Shier, A.C.; Xie, W.; Mirocha, C.J. Structure-activity relationships for human estrogenic activity in zearalenone mycotoxins. Toxicon, 39, 1435-1438, 2000.

43. Soares, L.M.V. Micotoxinas em milho de pipoca. IX Encontro Nacional de Micotoxinas, São Paulo, 1990, p. 52.

44. Soares, L.M.V.; Furlani, R.P.Z. Micotoxinas em milho para pipoca. Bol. Soc. Bras. Ciênc. Tecnol. Aliment., 26, 33-36, 1992.

45. Soares, L.M.V.; Rodriguez-Amaya, D.B. Survey of aflatoxins, ochratoxin A, zearalenone, and sterigmatocystin in some Brazilian foods by using multi-toxin thin-layer chromatographic method. $J$. Assoc. Off. Anal. Chem., 72(1), 22-26, 1989.

46. Solovey, M.M.; Somoza, C.; Cano, G.; Pacin, A.; Resnik, S. A survey of fumonisins, deoxyvalenol, zearalenone and aflatoxins contamination in corn-based food products in Argentina. Food Addit. Contam., 16(8), 325-329, 1999.
47. Tanaka, T.; Hasegawa, A.; Yamamoto, S.; Lee, U.S.; Sugiura, Y.; Ueno, Y. Worldwide contamination of cereals by the Fusarium mycotoxins nivalenol, deoxynivalenol, and zearalenone. 1. Survey of 19 countries. J. Agric. Food Chem., 36(5), 979-983, 1988.

48. Vargas, E.A.; Preis, R.A.; Castro, L.; Silva, C.M.G. Co-occurrence of aflatoxins $B_{1}, B_{2}, G_{1}$ e $G_{2}$ zearalenone and fumonisin in Brazilian corn. Food Addit. Contam., 18(11), 981-986, 2001.

49. Veldman, A.; Borggreve, G.J.; Mulders, E.J.; Van de Lagemaat, D. Occurrence of the mycotoxins ochratoxin A, zearalenona and deoxynivalenol in feed components. Food Addit. Contam., 9(6), 647-655, 1992

50. Vrabcheva, T.; Usleber, E.; Dietrich, R.; Märtlbaver, E. Co-occurrence of Ochratoxin A and Citrinin in Cereals from Bulgarian Villages with a History of Balkan Endemic Nephropathy. J. Agric. Food Chem., 48, 2483-2488, 2000.

51. Zummo, N.; Scott, G.E. Interaction of Fusarium moniliforme and Aspergillus flavus on Kernel infection and aflatoxin contamination in maize ears. Plant Dis., 76, 771-773, 1992. 